\title{
Vi skal se det fra de pårørendes side! Av Solveig Bøhle
}

Gunnar Gran var en profilert leder i Medie-Norge giennom 40 år og vil særlig bli husket som nyhetsmann. Da han døde 16 juni i år var det hans innsats som leder i nyhetsavdelinger i Aftenposten og NRK radio som ble framhevet. Mindre kjent er hans klarsyn og mot som var avgiørende for åpenhet om selvmord i det norske samfunnet. Det var i Gunnar Grans tid som radiosjef i NRK at radioen brøt tausheten om selvmord i Norge.

Sentrale personer i det psykiatriske fagmiliøet i Norge frarådet mediene å snakke om selvmord; bortsett fra litt statistikk var det stille i NRK og aviser fordi fagfolk var redd for at mediefokus på selvmord ville skape smitteeffekter, og flere selvmord ville skje.

Gunnar Gran brøt denne tausheten da han tidlig i 1980årene ga klarsignal til å omtale selvmord i NRK radio: "Men vi skal se det fra de pårørendes side", var hans klare holdning.

Første radioserien kom på lufta i 1984. De pårørende sto fram anonymt. Det tok flere måneder å få kontakt med de første som ble interviuet, men fordi pårørende ofte vet om hverandre var det snart flere familier som sa ja til å bli interviuet.

Programmene i serien ble lyttet på av Gunnar Gran og andre ledere før de ble sendt på lufta og etter sendingene satt ti telefonvakter klare og lyttet til innringernes behov for selv å fortelle. Reaksjonene var entydig positive også fra fagfolk som hørte radioprogrammene. Noen pårørende fortalte at første reaksjonen da serien ble annonsert var: "Slikt kan man ikke snakke om i radioen. Det er for vondt
Det var i

Gunnar Grans tid som radiosjef i NRK at radioen brot tausheten om selvmord i Norge og vanskelig for oss som har opplevd det samme". Likevel, de bestemte seg for å lytte og følte fellesskap og takknemlighet med alle som turte å stå fram: "Det de fortalte er akkurat slik også jeg har det", sa en kvinne, "selv i dag, to år etter at mannen min tok sitt liv er jeg redd, og jeg har så mange spørsmål. Jeg og barna ber om svar på spørsmål som alltid vil stå ubesvart, men kanskje har vi funnet en løsning i det å være mer åpne og snakke sammen".

De innringerne som onsket det fikk snakke med psykiater Kåre Duckert, eneste fagperson som var intervjuet i selve radioserien. Samtalene ble tatt opp dersom innringer sa det var greit, ingen samtaler gikk ut på lufta. Men disse opptakene og notater fra telefonvaktene ga et viktig kontaktnett med pårørende fra hele Norge og ble et verdifullt kildemateriell til neste radioserie og også boken Noen blir tilbake når et menneske tar sitt liv som kom i 1988.

Radioseriene, boken og dessuten fiernsynsserien Tausheten etterpå som ble sendt på NRK 1 i 1990 var begynnelsen til større åpenhet om selvmord i Medie-Norge. Det begynte med Gunnar Grans klarsyn, en radiosjef som trodde på ansvarlig åpenhet og hvor viktig det var å se det det fra de pårørendes side. 